\title{
On the centenary of the Spanish Institute of Oceanography
}

The journal Scientia Marina and the Institute of Marine Sciences (ICM-CSIC) wish to express their sincere congratulations to the Spanish Institute of Oceanography (IEO) on its $100^{\text {th }}$ anniversary.

Odón de Buen, the IEO's founder, had a strong and productive relationship with Barcelona. His tenure as Professor of Natural History at the University of Barcelona between 1889 and 1911 and his active participation in the social and scientific life of the city left a mark, disturbing a clerical and conservative society and inspiring young people eager for change. One of de Buen's students, José Fuset, taught Francisco García del Cid, founder of the ICM, so we think that he also somehow inspired the creation of our Institute. Since then, scientists from both the IEO and the ICM have collaborated in research projects covering all aspects of marine sciences, whose results have ended up in a great number of co-authored papers published in Scientia Marina and elsewhere.

One hundred years is a long time, especially considering the vicissitudes that this part of the world has gone through since 1914. Over the last 100 years rationality has been threatened by wars, dictatorships, obscurantism and crises, and science has often been deprecated. Odón de Buen was sadly a witness to those times and died in Mexico as a political refugee.

Despite all, the IEO has learned to sail through rough seas. With a renewed fleet of research vessels and the recruitment of young scientists, the IEO has set a steady course. May the spirit of its founder live on in the Instituto Español de Oceanografía in the many years to come.

On behalf of the Institute of Marine Sciences and Scientia Marina

Happy 100th Anniversary!

Editorial board of Scientia Marina

Dr. Albert Palanques

Director, Institute of Marine Sciences (CSIC) 